\title{
Marital Captivity Under the Era of Globalisation: A Sociological Analysis
}

\author{
Suman Srivastava* \\ Department of Sociology, Ranchi University, Ranchi, India \\ *Corresponding author: Department of Sociology, Ranchi University, Ranchi, India
}

Received: 留July 22, 2019

Published: 眥 July 30, 2019

\begin{abstract}
The process of globalization sweeping the world is exerting its unnoticed forces to redefine 'marriage' and 'family'. The forces of globalization and market are influencing the family structure and marriage norms to a large extent. Institution of marriage and the existence of a 'family' as a unit have found a new meaning. This new meaning is very often dictated by the market forces. The notion of family is shrinking, from large joint families, to nuclear families to individual or 'autonomous family' constituted by single person. This move that has been precipitated by the process of globalization has both positive and negative fallouts. On the one hand, this new found freedom promotes acceptance for such a process and allows the nuclear family to democratize and negotiate better living conditions. Women find their freedom to enter job market and earn enough for buying all material needs. Modernity has promoted women's empowerment through education, legal reforms, political power, economic and personal autonomy, and social mobilisation for gender justice.

Women, though allowed to earn, are incapacitated by lack of control over their own resources and earnings and suffer discrimination and violence. Thus the changes are more superficial than penetrating. The women may have entered the public arena, but the family values dominate and marital captivity is kept as a closely guarded secret. In the private arena, at the level of the family, the family is still dominated by patriarchal norms. Many traditional values and norms take new forms which may be detrimental to old social arrangements, such as providing family support systems to women. According to studies, one of the definite fallouts of globalization and marketization has been growing incidence of marital captivity on women. The important questions at this point are whether the process of globalization and the market forces and changing societal structures is inducing more violence into the lives of women, or they provide a new power in hands of women to come out of the patriarchal dominance and exert their rights to fight violence. This paper shall analyze the impact of globalization and market forces on changing nature of family and marriage and its relationship with growing marital captivity in India. To understand the change in society and its influences on marital captivity in the context of globalization, some references have been drawn from studies and researches in Europe, United State, India and Japan in this paper. The paper attempts to put across a model for combating marital captivity against women in the new era of globalization.
\end{abstract}

Keywords: Globalisation; Women; Marital Captivity; East Asia; Patriarchy; Family

\section{Introduction}

India has been ranked 114 in a list of 128 countries closely followed by Nepal (125) and Pakistan (126) on the Global Gender Gap report by the World Economic Forum (WEF). "The data captures the magnitude of the gap between men and women in critical areas including economic participation and opportunity, political empowerment, educational attainment, health and survival, female life expectancy and sex ratio at birth [1]." The incidence of crimes committed against women in India has seen a continuous rise over the years. Crimes against women increased [2]. However, the reported number of cases of marital captivity may grossly underestimate the true number of women experiencing marital captivity as many incidents go unreported owing to a lack of effective documentation, the stigma of victimization in Indian society, and fear of social disorganisation, all of which may inhibit distraught women from soliciting help. The condition of violence committed against women may be traced at its roots to the characteristically patriarchal structure of the family and society at large that fosters the imbalanced power ratio between men and women. The colossal transcendence of women in the work economy of the country since independence has had little effect in eliminating violence against 
them. There is a case of cruelty by husbands and relatives every nine minutes, and one dowry-death case every 77 minutes [3]. Crime against women touched a new high in 2007 with 185312 registered cases of crime against women. The dowry deaths alone totaled at 8093 with 75930 other cases registered under the 498A cases of cruelty by husband or relative against the married women. In a recent study conducted by Family Health Survey it has been found that nearly five crore married women in India suffer from Marital captivity. Just 1 out of 1000 cases of marital captivity case gets reported. And out the 100 cases that are investigated under 498A of the Indian Penal Code (IPC), the accused gets conviction only in 2 cases.

The reported cases of marital captivity in India represent only the tip of the iceberg which means vast majority being socially and institutionally invisible4. As the "iceberg" image suggests, recorded or official cases represent only a minimal portion of the problem of family violence in society. The majority of cases of violence fall "below the water line", invisible both socially and institutionally. In India, this iceberg theory has been reiterated by several studies, research papers and experience of NGOs working for the victims of marital captivity. For example, according to NFHS-3 Study5, which was conducted in 2005-06, where 124,385 women in the age group of 15-49 years were interviewed. Overall, 39\% of currently married women age 15-49 have ever experienced any physical or sexual or emotional violence in their current marriage and $27 \%$ have experienced the violence in the past 12 months. Thus, among all currently married women who have experienced physical, sexual, or emotional violence, more than two-thirds (68\%) have experienced the violence in the past 12 months and are likely to be still at risk.

In India safe 2000 multi-site study of nearly 10,000 households, 40 percent of the women reported experiencing at least one form of physical abuse and 26 percent reported severe physical abuse, including being hit, kicked, or beaten. UNFPA also reports that $40 \%$ of the women in India suffer marital captivity and abuse from male partner. Those that come forward often do so only after abuse have escalated to a point of severe, life-threatening violence. Records from the Special Cell for Women and Children in Mumbai, established by the Police Commission to provide a range of support services to women and their families, revealed that 43 percent of women endured marital captivity for 3-17 years before complaining to police6 (Dave and Solanki 2000). Census 2001 data shows that a total of 2,367,72,617 women are married. according to NFHS -3 data. $81 \%$ of currently married women age 15-49 who have ever experienced physical or sexual violence by their current husbands, the first time was within five years of marriage. It also reports that $37 \%$ of currently married women aged $15-49 y$ rs have experienced physical or sexual violence, and one in seven of all currently married women, have suffered an injury due to violence by their husbands.

\section{Changing Institution of Marriage in India}

Indian marriage systems are going through a major transition due to the impact of globalization on basic social values and institutions. The institution of marriage can be assessed by comparing and contrasting traditional and contemporary marriage patterns. The traditional pattern was marked by prominence of arranged marriages which were primarily oriented towards creating alliances between two families through "classical matchmakers" such as family priests and relatives. In such a marriage there was only a minor role for the bride and bridegroom in the context of decision-making regarding the marriage. Contemporary marriage, however, is based more on an understanding between the aboutto-be-married man and woman along with attention to the views of family elders. New "mediators" such as the media (matrimonial columns) and marriage bureaus have also emerged, contributing to the rise of a nationwide, and sometimes transnational, system of information and choice-making in the context of marriage.

Similarly there is a noticeable shift from an exclusive focus upon the physical attributes of the bride and economic assets of the bridegroom to the intellectual and economic characteristics of the bride and personality-related attributes and career prospects of the bridegroom. Today, we see a slight shift in the way traditional marriages are arranged. The strong presence of the audio, video, and print media, supported by the Internet has influenced the marriage scene tremendously. Open any newspaper on a Sunday and you will see hundreds of advertisements of prospective brides and grooms. Type the word "matrimonial" in any search engine, and see the list of countless websites for Asian marriages, Indian marriages, Hindu marriages, Muslim marriages, and Christian marriages. These matrimonial advertisements may sound amusing to the west, but they are pervasive not only in India but in the entire South Asian region. In earlier times, people tended to live in joint families and it was easier to find the prospective bride or groom from amongst the relatives of the family members. For example the eldest daughterin-law of the house could suggest her maternal aunt's daughter as a match for her younger brother-in-law. However, as traditional families started breaking up, and people started moving to cities for work, this form of arrangement started to break down. So there was a need for an alternative system of finding the ideal bride or groom. And the print media such as newspapers and magazines came to the rescue. The audiovisual media soon followed. Today, the print media and the Internet provide the easiest and fastest method for finding a suitable partner. The role of "marriage arranger" who used to be a priest or a relative has been taken over by the new media. Marriage Bureaus are popping up like mushrooms. Depending on how much you are willing to pay, they do anything from giving the "right advertisement" in the media, scrutinizing the resumes, sending the selected resumes for your approval, arranging the meeting of the two families, and also undertaking private investigation to check for the character and the details mentioned in the resume of the prospective candidate. They plan the weddings and take commission as a percentage of the amount spent on the marriage! Needless to say their businesses are booming because they keep themselves updated with the latest trends in the marriage market. A glance at the marriage advertisements confirms that religion, caste and sub-caste continue to dominate as criteria for spousal selection. The advertisements are arranged according to the castes and sub-caste and invite responses from families belonging to the same class or caste. The only change, over time, is in the method by 
which marriages are arranged, and not in the parameters by which a suitable match is evaluated.

\section{Marriage, Market and Dowry Related Violence}

The major influence that has been cast by globalization is an over-exposure to, and increased presence of worldly pleasures and luxury items, which are now essential items of dowry. The markets are flooded with household goods such as refrigerators, televisions, audio systems, DVD players etc. The bride's family is expected to give the latest model of these branded items as dowry or gifts at the time of marriage. It is an issue of prestige and the status of the family depends upon it. Dowry (and bride price in certain communities) has always had a universal presence in Indian marriage. The list of items in dowry or items given as gifts to the groom's family has changed over the years according to the market trends. But they are all there in some form. The more educated the boy, the more the demand for dowry and the more lavish the party. The dowry can vary from household items to fancy cars and apartments. The story does not end here. The bride's family is also expected to throw a lavish and extensive marriage party, which may be preceded by cocktail dinners and Ladies Sangeet (a day when songs of marriage are sung), and the Mehndi Night (where henna is put on the hands and feet of the bride by her friends and relatives). The bride's family has to spend a huge amount to call the party to sing the marriage songs and the henna could cost anywhere from Rs. 100 (US\$2.20) to Rs. 10,000 (US\$220) for a hand depending upon the social status and the family's ability to pay. Beauty parkours would charge anywhere between Rs. 2000 (US\$44) and Rs. 20,000 (US\$440) for the bridal make-up. There are "month before marriage" beauty packages available that could cost anywhere between Rs. 5,000 (US\$110) and Rs. 20,000 (US\$440) [4-6].

The bride's family is also expected to pay for all the rituals that precede the marriage and that happen at the time of marriage. This includes the fee of the priest, the arrangements made for the rituals, and the gifts to be given to the boy's family and the relatives. Polishing schools are also flourishing, and it is the fashion to attend these schools before marriage. Since most households are large families, where the boy shall be staying with his parents even after marriage, the innovators in the marriage market have started "Training Schools for Prospective Daughters-in-law", where the girls are being trained on how to get along with their mothersin-law and how to fit exceptionally well into the traditional role of an ideal daughter-in-law. These schools are gaining popularity amongst the middle-class. The India daily soap opera industry is highly influenced by the marriage institution, and barring a few T.V. serials, which have few takers, the entire visual media is dominated by the "Mother-in-law \& Daughter-in-law" episodes. These T.V. daily soaps on one hand show the "New Woman", who is independent, intellectual, and a decision-maker and on the other hand show women as traditional, homemaker, and the ideal daughter-in-law. This new image of women, for which the serial directors are largely responsible, (though they would say that they make films only about what the people want to see), puts them in a double-edged bind. A woman is supposed to work and earn for the family as well as do the household chores with the same vigor and enthusiasm as their non-working mothers-in-law display or used to display. This double jeopardy is a result of the new marriage norms that have been slowly evolving.

The boy looks for a girl who is beautiful, smart, intellectual, and sporty because she has to accompany him at all company dinners and parties and yet she should be traditional because she has to gel with his mother and father and fit into the traditional role. The roles of men are changing, but for women they are causing an excess burden. A look at the marriage advertisements shows that the boys' families look for a fair, slim, convent-educated, professional girl from a respectable family. Some even hint at the expected dowry. They also want a working girl. In addition to all this, the girl should also be homely and should know cooking and be able to manage the house. Moreover, there is no decrease in the amount of dowry, even if the girl possesses all the desired characteristics. The latest National Crimes Record Bureau data shows that dowry deaths and torture by husband has been increasing. If we include all the marriage related violence, the data shows that there is a consistent increase in cases related to dowry deaths and violence by husband and his family on the bride. Moreover, among all categories of CAW, Cruelty by Husband and Relatives has shown an increase of 20.3 between the years 2006 to 2007. Thus, the globalization and economic power in fact are precipitating marital captivity because there is a greater demand of resources. There is an increasing need of commodities and luxuries.

\section{Institutional Mechanism: Protection of Women from Marital Captivity}

This enactment is a big step in the direction of fighting marital captivity against women and goes a long way in protecting the women from violence in a domestic set up. Women could always approach the Courts under the IPC but the provisions were never so expansive. The term 'marital captivity' has never been used in IPC nor is it a gender specific law. The criminal law basically dealt similar cases of cruelty against married women, all other acts of marital captivity were not specifically criminalized. Also, no protection or residence orders were given to enable the woman to continue staying in the matrimonial house. This greatly restricted the women from approaching the Courts as most of them are dependents on their assailants and live under the fear of being turned out. The PWDVA is a civil law, where the aim is to provide relief to the aggrieved woman. The magistrate can pass Protection orders, residence orders, compensation orders, grant monetary relief under this law.

For the first time, marital rape has been recognized as an offence under this Act. The Act also provides for appointment of Protection Officers and Registered Service Providers to aid the aggrieved woman in accessing justice. The act, by and large, is a valuable piece of legislation. It provides protection to women, without considering their religion, and hence affords protection from discriminatory personal laws. The responsibility of the implementation lies on the executive, that would go on to prove the actual effectiveness of the Act. 


\section{Democratization for Combating Marital Captivity}

In order to effectively combat marital captivity, we must closely examine why our society has ignored or denied this issue. The most important reason is that in world men and women are not equal socially, economically or politically, in both private and public life. This inequality reflects the strong patriarchal structure of the family and society as a whole. This unequal status continues despite a constitution which clearly guarantees equality between the sexes. The fallouts of the process of globalization and market forces on growing marital captivity against women can be combated effectively if the family and society give equal power to women and the state mediates and facilitates the democratization of the family by enacting gender just laws and formulating and implementing gender just policies and programs. Women participation and access to resources is actually a manifestation of the democratic processes that exist within the Family, the Society and the State. The more democratic the structure, the more is the power given to women.

\section{There are three Steps to Democratization for Combating Marital Captivity:}

a) Democratization of family to allow women to be equal partner in decision making

b) No discrimination between sexes in society

c) Equal representation of women in state

These three conditions must co-exist to eliminate violence against women. If one of these conditions is missing, violence remains in the life of women. For example, In United States, the family is individualized, the society apparently does not discriminate between sexes, but the violence persists because the women are not equally represented in Parliament and decisionmaking bodies. In Sweden, women have reached in appreciable numbers in the Parliament and other decision-making bodies. They are more or less equally represented in state structures. But this alone has not been able to curb violence. In closed family system of highly industrialized nation such as Japan, women form an appreciable part of the work force. However, the family is not democratized and women are also not represented in equal number in state institutions. They continue to suffer violence. Looking at India, the Indian family is highly undemocratic, women representation at state and national structures is negligible and the society is devoid of gender justice. However, in the wake of globalization, which is throwing new challenges, is there also a hope

This work is licensed under Creative Commons Attribution 4.0 License

To Submit Your Article Click Here: Submit Article

DOI: $10.32474 /$ SJPBS.2019.02.000145 or a possibility of molding the market forces to the advantage of the women? Possibilities such as where the family structures start to democratize, women come forward to participate in the political process and the society starts valuing the contribution of women.

\section{Conclusion}

The process of globalization is not new. The globalization of the economic, social, cultural and political structures happened in all ages. Earlier the pace of such a process was so slow that we hardly noticed it. However, today with the advent of the information technology, newer means of communication have made the world a very small place. Not only the pace of the globalization process, but the penetration and integration of the changes induced in our day to day life has made the impact of globalization many fold higher. With this process the world has become one huge marketplace. However, fallout of such a process is that increasing marital captivity has been reported in most of the countries including industrialized nations, as a result of family fragmentation and loss of social support systems in marriage. Accompanying the increased burden for women is an increase in the level of all forms of violence, including marital captivity. It has been seen that when the society imposes sanctions against the perpetrators of violence, the women are empowered to exert for their rights. Only when the family and the society are democratized, the status of the women is strengthened. At this time, it becomes the duty of the state to facilitate and strengthen the process. The solution lies in the fact that women empowerment approach to combat violence against women should be well integrated and interwoven into all policies and programs of the governments. Women should be equal partners not only at the public places but should have adequate control of their own resources.

\section{References}

1. Rajalakshmi TK (2007) Woman as Victim. Frontline 24(25).

2. (2006) Women and Men in India, the Central Statistical Organisation (CSO), the Ministry of Statistics and Programme Implementation.

3. (2005) National Crime Records Bureau Report.

4. (2003) Social Visibility and Tolerance to Family Violence. Enrique Gracia, Universitat de Valènci a Psychology in Spain 7(1): 39-45.

5. (2009) National family Health Survey-3, August 2009, International Institute for Population Sciences, Mumbai, India.

6. Dave A, Solanki G (2000) Domestic Violence in India- A summary report of four research studies, Washington D.C. International centre for research on women.

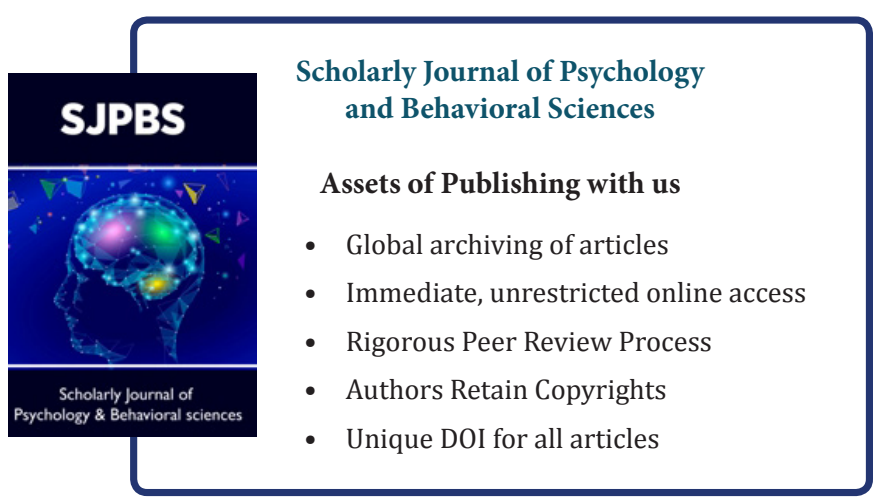

